\title{
POLSKA EMIGRACJA NIEPODLEGŁOŚCIOWA W LIBANIE 1943-1950 NA TLE UCHODŹSTWA POLSKIEGO CZASÓW II WOJNY ŚWIATOWEJ
}

\begin{abstract}
POLISH INDEPENDENCE DIASPORA IN LEBANON IN THE YEARS 19431950 IN THE LIGHT OF POLISH EMIGRATION DURING WORLD WAR II

The aim of this article is to discuss Polish Diaspora in Lebanon in the years 1943-1950 in the light of Polish emigration during World War II. It was Lebanon where an important immigration center was born when the Polish government in exile in London lost Soviet recognition in favor of the new communist government based in Warsaw. This was possible due to numerous domestic as well as international political and social factors, making possible the free development of institutions of Polish Diaspora in Lebanon.
\end{abstract}

Key words: diaspora, Lebanon, institutions, emigration

Słowa kluczowe: uchodźstwo, Liban, instytucje, emigracja

W zachowanej korespondencji pomiędzy brygadierem Maurice'em Lushem, dyrektorem International Refugees Organization (IRO) ${ }^{1}$ na Bliskim Wschodzie, a główną siedzibą organizacji w Genewie wielokrotnie powraca wątek polskich uchodźców w Libanie i ich „nietypowości”, komplikującej wszelkie działania zmierzające do repatriacji lub emigracji. Specyfika uchodźstwa w Kraju Cedrów na tle ogółu polskiego uchodźstwa wojennego dotyczyła wielu aspektów. Jej zrozumienie wymaga przybliżenia kontekstu

1 W niniejszym artykule wymieniane są dwie główne organizacje międzynarodowe odpowiedzialne za rozwiązanie problemu uchodźstwa po II wojnie światowej: Administracja Narodów Zjednoczonych do Spraw Pomocy i Odbudowy (ang. United Nations Relief and Rehabilitation Administration) oraz Międzynarodowa Organizacja ds. Uchodźców (ang. International Refugees Organiz̨ation). 
historycznego końca II wojny światowej oraz wczesnego okresu powojennego. Działania wojenne oraz związane z nimi deportacje zmusiły do opuszczenia miejsca zamieszkania około 5 milionów obywateli polskich, z których większość znalazła się na terenie byłych państw osi². Polacy, wraz z obywatelami innych krajów środkowej i wschodniej Europy, stanowili najliczniejsza grupę narodową wśród społeczności dipisów ${ }^{3}$.

Polskie uchodźstwo wojenne pod żadnym względem nie było politycznie lub społecznie jednolite. Na tę różnorodność składało się wiele czynników, takich jak historia lub pochodzenie uchodźców. Dipisi obecni w Niemczech i Austrii pochodzili w znacznej mierze z okupowanych ziem II Rzeczypospolitej. W czasie wojny byli oni przeważnie przymusowymi robotnikami pracującymi na terenie III Rzeszy. Natomiast zdecydowana większość uchodźców przebywających po 1945 r. w Afryce i na Bliskim Wschodzie zamieszkiwała przed wojną tereny zajęte przez ZSRR we wrześniu 1939 r. Po deportacji w głąb ZSRR przedostali się oni do Iranu wraz z armią gen. Władysława Andersa. Tym samym Polacy w Libanie różnili się od swoich rodaków w Europie nie tylko pod względem pochodzenia, ale także z punktu widzenia doświadczeń czasu wojny. Odmienność przeżyć prowadziła również do różnorakich reakcji na wydarzenia w Polsce i wpływała na stosunek uchodźców do nowych władz komunistycznych w Warszawie.

Przypadek polskiego uchodźstwa w Libanie pozwala też na przestudiowanie relacji uchodźców z organizacjami międzynarodowymi odpowiedzialnymi za rozwiązanie kwestii Displaced Persons. Podczas gdy w obozach uchodźczych w Europie DPs byli całkowicie zależni od decyzji władz United Nations Relief and Rehabilitation Administration (UNRRA) lub International Refugees Organization (IRO), w Libanie stosunki między uchodźcami a wspomnianymi agendami były w dużej mierze efektem negocjacji. W ramach niniejszego artykułu pragnę pokazać, opierając się na przykładzie polskich uchodźców w Libanie, że relacje te były w znacznym stopniu uzależnione od poziomu wewnętrznej organizacji uchodźstwa, postawy lokalnych władz, a także od opcji politycznej dominującej wśród przedstawicieli danej grupy uchodźców.

Kwestia polskiego uchodźstwa w Libanie była ściśle związana z wydarzeniami politycznymi w Polsce oraz na arenie międzynarodowej. Uznanie przez światowe potęgi komunistycznego Tymczasowego Rządu Jedności Narodowej (TRJN) w Warszawie doprowadziło do podziałów wśród Polaków oraz do walki ideologicznej między Warszawą a polską emigracją niepodległościową. Dla TRJN repatriacja wszystkich uchodźców stała się priorytetem ze względów politycznych i prestiżowych. Stworzenie jak najliczniejszej

K. Kersten, Repatriacja ludności polskiej po II wojnie swiatowej, Warszawa 1974, s. 61.

3 Termin dipis, będący spolszczoną odmianą skrótu „DP” odnoszącego się do angielskiego określenia Displaced Person (dosł. „osoba przemieszczona”), stosowany był, aby określić wszystkich uchodźców wojennych. W niniejszym artykule używam również terminu uchodíca, który lepiej odzwierciedla specyficzną sytuację Polaków w Libanie. 
opozycji za granica wobec nowych władz w Polsce dawało rządowi emigracyjnemu w Londynie nadzieję na zachowanie roli politycznej na arenie międzynarodowej po 1945 roku. W efekcie pierwsze lata powojenne poprzedzające eskalację napięć między Wschodem a Zachodem naznaczone były walką polityczną pomiędzy obydwoma obozami, która w różnoraki sposób znajdowała swoje odzwierciedlenie w terenie.

Dotychczasowe prace historyczne skupiały się głównie na wyzwaniach administracyjnych i logistycznych, jakim podołać musiały instytucje takie jak IRO lub UNRRA, niewiele poświęcając przy tym miejsca stosunkom panującym pomiędzy ich przedstawicielami a uchodźcami. Temat uchodźstwa po II wojnie światowej na terenie Europy jest opisany najbardziej wyczerpująco, w szczególności przez historyków anglosaskich, takich jak Daniel Cohen lub Anna Holian4. Ich dzieła pozostają głównymi pozycjami naukowymi w tej dziedzinie. Eurocentryczny wymiar historiografii uchodźstwa uzupełnić można pracami polskich historyków, z których wiele poświęconych zostało historii polskiego uchodźstwa w Afryce i w Azji ${ }^{5}$.

Dzieje polskiego uchodźstwa w Libanie były pomijane zarówno ze względu na jego nietypowość, jak i z powodu jego stosunkowo marginalnego wymiaru. Dzieło autorstwa Jacka Pietrzaka zatytułowane Polscy uchodźcy na Bliskim W schodzie w latach II wojny swiatowej. Ośrodki, instytucje, organizacje, wydane w 2012 r., jest de facto pierwsza publikacją akademicką, w której zostało ono uwzględnione ${ }^{6}$. Wspomnieć należy także pracę Jana Drausa na temat oświaty i nauki polskiej na Bliskim Wschodzie ${ }^{7}$. Historia Polaków w Libanie jest bardzo dobrze udokumentowana dzięki zabiegom byłych uchodźców, z których większość po wojnie zamieszkała w Wielkiej Brytanii. Głównymi źródłami informacji sa prace byłych uczniów ośrodka w Isfahanie, a także zbiór wspomnień polskich studentów bejruckich uczelni ${ }^{8}$. Niewielka Polonia w Libanie również przyczynia się do kultywowania pamięci o polskim wychodźstwie w tym kraju?

$4 \quad$ Wymienić można co najmniej kilka prac na temat powojennego kryzysu uchodźczego: D. Cohen, In War's Wake: European Refugees in the Postwar Order, Oxford 2011; A. Hilton, Between National Socialism and Soviet Communism, Displaced Persons in Postwar Germany, Michigan 2011; K. Salomon, Refugees in the Cold War: Toward a New International Refugee Regime in the Early Postwar Era, Lund 1991.

$5 \quad$ W przypadku historii uchodźstwa polskiego w Afryce jedna z obszerniejszych prac na ten temat jest dzieło J. Wróbla: Rozproszeni po świecie. Obosy i osiedla uchodźcón polskich ze Zwiqaku Sowrieckiego 19421950 (Chicago 1992). Wspomnieć należy także o pracach H. Zins a: Polacy w Afryce Wschodniej (Lublin 1978) oraz Polacy w Zamberji (Lublin 1988).

6 J. Pietrzak, Polsy uchodźcy na Bliskim Wschodzৃie w latach II wojny światowej. Ośrodki, instytucje, organizacje, Łódź 2012.

7 J. Draus, Oswriata i nauka polska na Bliskim i Środkonym Wschodzie. 1939-1950, Lublin 1993.

8 Isfahan, the City of Polish Children, eds. I. Beaupre-Stankiewicz, D. Waszczuk-Kamieniecka, J. Lewicka-Howells, Londyn 1989; Pod cedrami Libanu, red. B. Redzisz, H. Adamiak-Wagner, H. Chojecka-Szeremeta, London 1994.

$9 \quad$ M. Zielinska-Schelamy, Cedri Orzet. Polacy w Libanie, niezrnylkte wspótistnienie, Bejrut 2012. 
Grupa libańska stanowi ciekawy temat badawczy pozwalający jak w soczewce dostrzec problemy związane z kwestią DPs po II wojnie światowej. Z obszernej dokumentacji pobytu Polaków w Kraju Cedrów wyłania się obraz ich życia codziennego, społecznego i politycznego. Przykład ten pozwala zaobserwować proces stopniowego przekształcania się uchodźstwa w emigrację. W niniejszym artykule pragnę zwrócić uwagę na różne aspekty codzienności Polaków w Libanie między 1943 i 1950 r. na podstawie archiwaliów pozostawionych przez różne instytucje uchodźcze, jak i przez samych uchodźców. W tym okresie rozwijały się polskie instytucje i organizacje emigracyjne w związku z napływem Polaków z Iranu. Należy jednak podkreślić, że byli oni obecni w Libanie od początku wojny, a ich liczba wahała się w ciągu całego omawianego okresu. Podobne ramy czasowe przyjął w swoim dziele o uchodźstwie polskim w Libanie Kamil Kantak, duszpasterz Polonii libańskiej do 1976 r. ${ }^{10}$ Od 1948 r. nastąpiła trwająca dwa lata stopniowa likwidacja ośrodka.

\section{Polski ośrodek uchodźczy w Libanie: zaplanowane przedsięwzięcie władz polskich i brytyjskich}

\subsection{Dlaczego Liban?}

Choć Polacy obecni byli w Libanie już od pierwszych lat wojny, w związku z formowaniem Brygady Strzelców Karpackich w Syrii, o powstaniu prawdziwej społeczności uchodźczej mówić można dopiero od końca 1943 r., gdy do Kraju Cedrów przybywać zaczęli cywile polscy z Iranu. Precyzyjne dane sporządzone przez konsulat, a później poselstwo polskie w Libanie pozwalają na ustalenie procesu powstawania ośrodka, który faktycznie zaczął kształtować się dopiero w 1944 r.

\begin{tabular}{|c|c|c|c|c|}
\hline Październik 1943 & Październik 1944 & Luty 1945 & Maj 1945 & Luty 1946 \\
\hline 57 & 291 & 372 & 776 & 4336 \\
\hline
\end{tabular}

Tab. 1. Liczba uchodźców polskich w Libanie między październikiem 1943 i lutym 1946 r. ${ }^{11}$

Z zachowanej korespondencji dyplomatycznej wnioskować można, że utworzenie polskiego ośrodka na Bliskim Wschodzie dla uchodźców pozostających w Iranie było

10 K. Kantak, Drieje uchodźstwa polskiego w Libanie 1943-1950, Bejrut 1955.

11 Instytut Polski i Muzeum im. gen. Sikorskiego w Londynie (dalej cyt.: IPMS), A 11 E 761, raport Z. Zawadowskiego dotyczący przyjazdu Polaków do Libanu z 28 XII 1944 r.; ibidem, telegram

Z. Zawadowskiego do Ministerstwa Spraw Zagranicznych Rządu RP na Uchodźstwie zawiadamiający o ewolucji liczby uchodźców polskich w Libanie z 28 V 1945 r.; ibidem, A 11 E 762, telegram 
brane pod uwagę już w sierpniu 1943 r. Do tej koncepcji przychylnie odnosił się generał Kazimierz Sosnkowski, który w listopadzie tego samego roku przebywał na Bliskim Wschodzie ${ }^{12}$. Pod koniec września do Bejrutu przybył Zygmunt Zawadowski, mianowany przez polskie władze emigracyjne konsulem generalnym w Libanie ${ }^{13}$. Ten doświadczony dyplomata, były pracownik poselstwa polskiego w Hiszpanii, Kujbyszewie i Teheranie, miał wzmocnić polską placówkę w okresie poprzedzającym przybycie Polaków do Libanu. Zawadowski był jednym z największych zwolenników powstania nowego ośrodka uchodźczego, na co wskazuje jego aktywność w pozyskiwaniu wiz indywidualnych dla pierwszych Polaków przybywających do Bejrutu. Po zdobyciu potrzebnych dokumentów uchodźcy przewożeni byli z Iranu do Libanu drogą lądową przez Irak i Syrię (głównie autobusami i koleja). Z powodów tak politycznych, jak i praktycznych ostatnia - i zarazem największa grupa Polaków obecna jeszcze w Iranie w 1945 r. - dostała się do Libanu na podstawie porozumienia zawartego między rządem emigracyjnym w Londynie i rządem libańskim w listopadzie 1945 r. Wielka Brytania stała się gwarantem tego porozumienia ${ }^{14}$.

Uzasadniając wybór Libanu, władze polskie najczęściej przytaczały względy polityczne, geograficzne i kulturowe. Klimat śródziemnomorski oraz niewysokie góry w sąsiedztwie morza tworzyły odpowiednie warunki dla Polaków, których zdrowie ucierpiało w czasie zesłania w głąb ZSRR. Liban był mocno zeuropeizowany i w znacznej mierze zamieszkany przez ludność chrześcijańska. Ponadto korzystne uwarunkowania panujące na lokalnej scenie politycznej miały okazać się kluczowe dla polskiego uchodźstwa w późniejszym okresie jego istnienia. Warto zauważyć, że polska społeczność była homogeniczna pod względem konfesyjnym, jako że władze libańskie niechętnie przyjmowały na swoje terytorium wyznawców judaizmu. Ci ostatni znacznie częściej trafiali do Palestyny.

Niepodległość uzyskana przez Liban na przełomie 1943 i 1944 r. sprzyjała utworzeniu polskiego ośrodka uchodźczego. Choć kraj pozostawał pod silnymi wpływami francuskimi i brytyjskimi, uzyskał on niezależność administracyjną i ekonomiczna. Zygmunt Zawadowski, będąc być może świadom potencjalnych korzyści politycznych z punktu widzenia sprawy polskiej, przekonywał swoich zwierzchników w Londynie, aby bezwarunkowo uznać niepodległość Libanu ${ }^{15}$. Przy braku wyraźnych instrukcji Zawadowski

Z. Zawadowskiego do Ministerstwa Spraw Zagranicznych RP na Uchodźstwie z 19 VII 1946 r. dotyczący liczby polskich uchodźców w Libanie.

12 Ibidem, A 11 E 365, raport dotyczący polskich uchodźców na Bliskim Wschodzie, niedatowany, sporządzony prawdopodobnie przez gen. Kazimierza Sosnkowskiego; J. Pietrzak, op. cit., s. 103.

13 IPMS, A 11 E 365, protokół przekazania konsulatu Rzeczypospolitej Polskiej Z. Zawadowskiemu z 30 IX $1943 \mathrm{r}$.

14 J. Waluszewska-Dukszta, „The New Reality”, [w:] Isfahan..., s. 387.

15 IPMS, A 11 E 762, list Z. Zawadowskiego do Ministerstwa Spraw Zagranicznych Rządu RP na Uchodźstwie, niedatowany. 
postanowił postawić rząd polski przed faktem dokonanym, uznając niepodległość Libanu i Syrii w deklaracji ustnej, w momencie składania listów uwierzytelniających prezydentom Shukriemu al-Quwwatly'emu i Becharze al-Khoury'emu w sierpniu 1944 r. ${ }^{16}$ Tym samym polski rząd na uchodźstwie jako jeden z pierwszych nawiązał stosunki dyplomatyczne z Republiką Libańska. Decyzja ta pozwoliła zachować przedstawicielom rządu londyńskiego oficjalny wymiar poselstwa pomimo uznania TRJN w Warszawie przez mocarstwa w lipcu $1945 \mathrm{r}$. W wymiarze praktycznym sytuacja ta pozwalała polskim dyplomatom komunikować się z władzami libańskimi bez pośrednictwa przedstawicielstwa brytyjskiego, sprawującego de facto kuratelę nad polskim uchodźstwem na Bliskim Wschodzie.

\subsection{Organizacja instytucjonalna polskiego uchodźstwa w Libanie}

Rozmieszczenie uchodźców w poszczególnych ośrodkach było starannie zaplanowane; brano pod uwagę ich sytuację rodzinną lub wiek. Nowo przybyłych kierowano do obozu tranzytowego zlokalizowanego na południe od Bejrutu, skąd trafiali oni do jednego z siedmiu ośrodków. Polacy najczęściej osiedlani byli w największych ośrodkach w Zouk, Ghazir i Baabdat, na północ od Bejrutu, gdzie znajdowały się główne polskie placówki szkolne (łącznie z gimnazjum i liceum), jak i w mniejszych ośrodkach w Roumy, Beit Chehab, Bdadoun i Ajaltoun. Ponadto w każdym ośrodku działała szkoła podstawowa ${ }^{17}$. Miejscowości mające przyjąć Polaków wybierane były przez przedstawicieli poselstwa i Ministerstwa Pracy i Opieki Społecznej (MPiOS) na podstawie określonych kryteriów, takich jak odległość od Bejrutu, wyznanie religijne mieszkańców czy też klimat. Niebagatelną rolę odegrał przy tym ojciec Peregryn Malinowski, polski misjonarz mieszkający w Libanie, który dobrze znał język arabski i społeczeństwo lokalne ${ }^{18}$. Prawie wszystkie ośrodki znajdowały się w regionie Metn, zamieszkanym w całości przez chrześcijan, w miasteczkach zlokalizowanych na pogórzu pasma gór Libanu o wysokości nieprzekraczającej 1000 m n.p.m.

Konsulat Generalny, w sierpniu 1944 r. podniesiony do rangi poselstwa, był główną instytucją uchodźczą w Libanie. Prowadzona przez Zygmunta Zawadowskiego aż do 1956 r., gdy władze libańskie zdecydowały się uznać rząd w Warszawie, placówka ta pozostawała jedynym oficjalnym polskim przedstawicielstwem w Libanie, pomimo wywieranych na władze w Bejrucie nacisków, aby uznanie to cofnąć. Poselstwo było głównym interlokutorem władz brytyjskich i organizacji międzynarodowych w okresie powojennym, choć wraz z oddalającą się perspektywą oczekiwanych zmian politycznych

\footnotetext{
16 J. Pietrzak, op. cit., s. 135.

17 J. Waluszewska-Dukszta, op. cit., s. 390-396.

18 Ibidem, s. 389.
} 
w Polsce jego znaczenie polityczne słabło. Najważniejszą instytucją dla samych uchodźców była delegatura MPiOS, odpowiedzialna za przydział zasiłków i kwestie socjalne. Po cofnięciu przez Londyn uznania dla polskiego rządu na uchodźstwie delegatura weszła w skład The Interim Treasury Commitee for Polish Affairs w Londynie (ITC), aby po objęciu spraw uchodźczych przez UNRRA stać się referatem do spraw polskich ambasady brytyjskiej w Bejrucie, pod nazwą Polish Refugees' Office (PRO). Pomimo zmian nazwy i struktury administracyjnej placówka ta pozostawała w gestii Polaków, na czele z Eugeniuszem Kocuperem i Michałem Tyszkiewiczem. Choć podejmowano próby ograniczenia władzy delegatury w zakresie spraw socjalnych, była ona główna instytucją wykonawczą aż do likwidacji uchodźstwa w 1950 r.

$\mathrm{Na}$ czele każdego polskiego ośrodka poza Bejrutem stał lokalny komitet uchodźczy podlegający delegaturze MPiOS, a następnie $\mathrm{PRO}^{19}$. Tym samym jego członkowie nie znajdowali się pod bezpośrednią kontrolą UNRRA i IRO, co dawało im relatywną autonomię działania, jaką nie cieszyły się podobne organy w obozach uchodźczych w Europie. Odbywające się corocznie wybory do komitetów nie służyły jedynie wpajaniu postaw obywatelskich, lecz w sposób rzeczywisty mogły mieć wpływ na wewnętrzne sprawy polskiej społeczności. Jak zaznaczał autor artykułu opublikowanego w maju 1949 r. na łamach „Polaka w Libanie”, wybory komitetów były jedynymi w skali całego uchodźstwa polskiego, których regulamin przypominał prawdziwe prawo wyborcze ${ }^{20}$. Członkowie komitetów lokalnych mieli wdrażać rozporządzenia przyjmowane przez MPiOS i regularnie uczestniczyli w spotkaniach między władzami polskimi i przedstawicielami międzynarodowych organizacji uchodźczych.

\section{Uchodźcy czy migranci? Warunki pobytu Polaków w Libanie}

\section{1. Życie codzienne uchodźców}

Skupiska Polaków w Libanie były rozproszone w promieniu około 50 kilometrów od Bejrutu, który szybko stał się największym polskim centrum w Kraju Cedrów. Uchodźcy mieli do dyspozycji wynajęte przez władze polskie mieszkania, przeważnie dzielone z libańskimi właścicielami. Zwiększająca się liczba uchodźców doprowadziła do powstania licznych instytucji polskich, takich jak poczty, piekarnie czy świetlice. Choć Bejrut stanowił największe skupisko Polaków w Libanie, trudno było mówić o „ośrodku uchodźczym”. Stolica przyciagała nie tylko liczniejszymi atrakcjami kulturalnymi, ale również swobodą i anonimowością, które były ograniczone w ośrodkach znajdujących

\footnotetext{
19 IPMS, A 11 E 761, Regulamin komitetów uchodźczych w Libanie.

20 „Polak w Libanie” 1949, nr 4/40, s. 16, sprawozdanie z przebiegu wyborów do komitetów uchodźczych w Libanie.
} 
się w górach. Także tutaj uchodźcy mieszkali w wynajmowanych lokalach, często zajmowanych przez kilka rodzin, lub w polskich akademikach dla studentów bejruckich uczelni. Mapa Bejrutu sporządzona w 1946 r. pokazuje, że polskie instytucje oraz akademiki nie koncentrowały się w jednej dzielnicy, lecz rozproszone były na terenie całego miasta ${ }^{21}$.

W czasie pobytu w Libanie Polacy na co dzień koegzystowali z ludnością lokalna i dostosowywali się do panujących warunków życia. Władze polskie przychylnym okiem patrzyły na tego rodzaju kontakty, piętnując przy tym wszelkie przejawy wrogości wobec libańskich gospodarzy. W długim artykule opublikowanym w „Przelotem”, głównym dzienniku polskim wydawanym w Libanie, autorzy ostro krytykowali wszelkie nadużycia, przypominając Polakom, że są oni tylko gośćmi lojalnymi wobec rządu i władz libańskich $^{22}$. Do otwartości na kulturę kraju przyjmującego uchodźców nawoływał także sam generał Władysław Sikorski w swoim wystapieniu przed korpusem dyplomatycznym 23 czerwca 1943 r. w trakcie wizyty w Bejrucie. Według niego zbyt mocne podkreślanie odrębności narodowej, a także odcinanie się od kultury i rzeczywistości lokalnej groziło utworzeniem polskich gett. Uchodźca winien był kłaść „nacisk na jak największe wykorzystanie przymusowego pobytu za granica, by wrócić do Polski z nowymi wartościami i wiedzą"23. Ciekawość inności i otwartość były więc także postawą patriotyczną.

Stopień interakcji uchodźców z kulturą i ludnością lokalną zależał w dużym stopniu od typu ośrodka. W Bejrucie Polacy wtapiali się w rzeczywistość miejska, nie ograniczając się do życia w zamkniętej społeczności, podczas gdy w małych miejscowościach poza Bejrutem związki między uchodźcami mogły być znacznie silniejsze (co nie przeszkadzało w nawiązywaniu kontaktu z ludnością libańska). Bez względu na miejsce zamieszkania nie sposób mówić o prawdziwej ,integracji” Polaków ze środowiskiem lokalnym, biorąc pod uwagę, że pobyt w Libanie zawsze postrzegany był przez uchodźców jako okres przejściowy, jakkolwiek nie byłby on długi. Jednak relacje z Libańczykami istniały, szczególnie wśród młodzieży. Liczne wspomnienia autorstwa byłych uchodźców odmalowują obraz prawie normalnej egzystencji, charakteryzującej się spokojem i beztroską, kontrastująca z niepewnością pierwszych miesięcy po zakończeniu wojny ${ }^{24}$. W niektórych przypadkach owa „normalność” nie była widziana przychylnym okiem przez władze uchodźcze, dla których pewne praktyki ujemnie wpływały na morale uchodźstwa.

Zgadzając się na przyjazd uchodźców, władze libańskie zastrzegły, że nie powinni oni stanowić żadnego obciążenia finansowego dla budżetu państwa ani dla lokalnego

21 IPMS, KOL 380/XB/1/11, plan Bejrutu, $1946 \mathrm{r}$.

22 „Przelotem” 1947, nr 62/252, s. 1.

23 Cyt. za: J. Ciechanowski, Konferencja Generała Sikorskiego w Bejrucie 23 kwietnia 1943, „Zeszyty Historyczne" 1985, nr 74, s. 139-148. Należy zaznaczyć, że w tytule artykułu prawdopodobnie wkradł się błąd, jako że wspomniana konferencja odbyła się 23 VI 1943 r.

24 S. Jasionowicz, Pamietam... i nie pamietam... Wybór wspomnień (1940-1950), Warszawa 2016, s. 71. 
rynku pracy, w wielu przypadkach Polacy poszukujący zatrudnienia byli zwalniani z tych przepisów. W perspektywie zanikających szans na rychły powrót do Polski władze londyńskie rozważały możliwości osiedlenia Polaków w dolinie Bekaa, we wschodniej części kraju, gdzie warunki pozwalały na utworzenie kolonii rolniczej. W swoim raporcie na temat możliwości aktywizacji polskich uchodźców w Libanie Rudolf Gilar, pracownik poselstwa, donosił o możliwości zatrudnienia na wykwalifikowanych stanowiskach, np. w przemyśle wydobywczym lub przy utrzymaniu sieci kolejowej, zajmowanych do tamtej pory przez Francuzów i Brytyjczyków. Według Gilara władze libańskie zwróciły się do przedstawicielstwa polskiego o pomoc w znalezieniu specjalistów i techników w celu eksploatowania linii kolejowej Bejrut-Hajfa po opuszczeniu Libanu przez armię brytyjską ${ }^{25}$. Autorzy raportu IRO dotyczącego polskich obywateli w Libanie również stwierdzali, że w Bejrucie wielu uchodźców znalazło zatrudnienie, otrzymując za to wynagrodzenie ${ }^{26}$. Za najlepszy przykład może służyć przypadek architekta Karola Szajera, który pozostał w Libanie aż do lat 70. i którego realizacje w duchu powojennego modernizmu trwale naznaczyły krajobraz urbanistyczny Bejrutu.

\subsection{Organizacje i propaganda}

Organizacje polskie działające w Libanie odgrywały znaczącą rolę w życiu codziennym Polaków. Nie sposób wymienić tutaj wszystkich stowarzyszeń i kółek powstałych $\mathrm{w}$ omawianym okresie, istnienie wielu z nich bowiem było w pełni zależne od przyjazdów i wyjazdów kolejnych grup uchodźców. Studencki „Bratniak”, którego działalność została bardzo dobrze udokumentowana przez jego byłych członków, był bez watpienia najprężniej działająca polską organizacją kulturalną w Libanie ${ }^{27}$. Nie brakowało także stowarzyszeń o charakterze politycznym, odzwierciedlających główne nurty Polski przedwojennej, jednak ich aktywność pozostaje słabo znana z powodu braku materiałów archiwalnych. Działalność szeregu organizacji charytatywnych, takich jak Polski Czerwony Krzyż lub polska YMCA, utrzymujące polską stołówkę i świetlicę w centrum Bejrutu, uzupełniała zapomogi otrzymywane od władz uchodźczych.

Liczne uroczystości o charakterze patriotycznym miały na celu podkreślić lojalność Polaków wobec polskiego rządu na uchodźstwie. Poza tradycyjnymi świętami państwowymi obchodzono szereg innych rocznic, takich jak dzień urodzin Prezydenta RP na uchodźstwie bądź też dzień św. Józefa na pamiątkę imienin Marszałka Józefa Piłsudskiego. Na szczególną uwagę zasługuje uroczystość odsłonięcia tablicy pamiątkowej upa-

25 IPMS, A 11 E 761, Rudolf Gilar, referat dotyczący możliwości zatrudnienia Polaków w Libanie z 2 VII $1946 \mathrm{r}$.

26 Archives Nationales in France (dalej cyt.: ANF), AJ/43/1059, sprawozdanie z działalności IRO na Bliskim Wschodzie z 28 VIII 1948 r.

27 Pod cedrami Libanu... 
miętniającej pobyt w Libanie Juliusza Słowackiego, która odbyła się 28 kwietnia 1946 r. w miejscowości Ghazir, gdzie powstać miał Anhelli. Po przemówieniu Zygmunta Zawadowskiego i odczytaniu poematu Smutno mi, Boże licealiści recytowali wybrane fragmen-

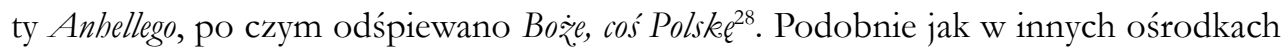
uchodźczych w Afryce i na Bliskim Wschodzie w tego typu ceremoniach szczególną rolę odgrywało duszpasterstwo polskie oraz harcerstwo. Każdemu wydarzeniu o charakterze państwowym towarzyszyła celebracja mszy świętej. Świętom katolickim także nadawano wyraz patriotyczny. W środę popielcową 1947 r. dziennik „Przelotem” wzywał do przestrzegania postu w geście solidarności z rodakami żyjącymi w komunistycznej Polsce ${ }^{29}$.

Choć organizacje odgrywały także ważną funkcje propagandową, ich poczynania nie zawsze spotykały się z aprobatą polskich władz uchodźczych oraz duszpasterstwa, co mogło prowadzić do spięć. W marcu 1947 r. przewodniczący wspomnianego wyżej „Bratniaka” weszli w konflikt z Zawadowskim, jego kuratorem, który zarzucał organizacji studenckiej skupianie się na aktywności niemającej związku z misją propagandową ${ }^{30}$. Od 1946 r. narastał również poważny konflikt pomiędzy poselstwem polskim w Bejrucie a członkami lokalnego biura Stronnictwa Narodowego (SN). Poseł Zawadowski otwarcie oskarżał w swojej korespondencji tych ostatnich o podejmowanie inicjatyw bez wiedzy poselstwa, które doprowadzały do osłabienia pozycji polskiej i sprzyjały tym samym agentom rządu warszawskiego. W odpowiedzi członkowie SN wytykali Zawadowskiemu, piłsudczykowi, dyktatorski styl zarządzania sprawami polskimi ${ }^{31}$. Echa konfliktu dotarły do Londynu, gdzie urzędnicy polskiego Ministerstwa Spraw Zagranicznych poważnie brali pod uwagę ryzyko utraty przez poselstwo w Bejrucie kontroli nad instytucjami uchodźczymi ${ }^{32}$.

W Libanie, gdzie skupiska uchodźców były rozdrobnione, prasa polska odgrywała kluczową rolę w pielęgnowaniu etosu przedwojennej Polski, a także w definiowaniu nowej „racji bytu” polskiego uchodźstwa powojennego. Dziennik „Przelotem”, wydawany pod auspicjami poselstwa, był głównym źródłem informacji w Libanie, a także instrumentem propagandowym władz polskich. Poza informacjami dotyczącymi bieżących spraw lokalnych gazeta publikowała liczne artykuły na tematy związane $z$ dalszą emigracją, zagadnieniami politycznymi, a także odezwy władz polskich do polskiej społeczności

28 IPMS, A 11 E 762, program ceremonii inauguracji tablicy upamiętniającej w Ghazir 28 IV 1946 r.

29 „Przelotem” 1947, nr 40/230, s. 2.

30 IPMS, A 11 E 761, list Z. Zawadowskiego do Ministerstwa Wyznań Religijnych i Oświecenia Publicznego Rządu RP na Uchodźstwie z 22 III 1947 r.

31 IPMS, A 11 E 762, list biura SN w Bejrucie do Z. Zawadowskiego z 14 IX 1946 r. dotyczący jego roli w instytucjach uchodźczych.

32 IPMS, A 11 E 762, list Ministerstwa Spraw Zagranicznych Rządu RP na Uchodźstwie do Z. Zawadowskiego z 10 III 1947 r. dotyczący autorytetu poselstwa w Bejrucie. 
w Kraju Cedrów. Poza „Przelotem” w Libanie ukazywały się biuletyny i periodyki różnych stowarzyszeń, spośród których wymienić należy „Polaka w Libanie” oraz „Pion”, główne czasopismo studenckie wydawane przez „Bratniaka”. W przeciwieństwie do gazet polskich publikowanych w obozach w Europie prasa w Libanie nie podlegała ścisłej kontroli władz brytyjskich lub organizacji międzynarodowych. O niebagatelnej roli gazet i periodyków świadczą zresztą meldunki, w których urzędnicy UNRRA wskazują na potrzebę wymuszenia na władzach polskich publikacji informacji dotyczących możliwości repatriacyjnych do Polski ${ }^{33}$.

Zaangażowanie polityczne i społeczne nie zajmowało jednak istotnego miejsca w życiu codziennym uchodźstwa polskiego w Libanie. Relacje studentów polskich wskazują na to, że debaty natury politycznej były rzadkie ${ }^{34}$. Spotkania w siedzibie „Bratniaka” w Bejrucie najczęściej dotyczyły kwestii uniwersyteckich oraz spraw bieżących, takich jak organizacja wydarzeń kulturalnych lub wyjazdów poza Bejrut. Aktywności polityczno-społecznej nie sprzyjał także zindywidualizowany tryb życia, szczególnie w stolicy. Przeciętny uchodźca nie orientował się w rozmiarach polskiej społeczności w Libanie, zaś jego kontakty z rodakami miały miejsce głównie na uniwersytecie oraz we wspólnie wynajmowanych mieszkaniach, często dotyczyły osób znających się jeszcze z czasu pobytu w Iranie ${ }^{35}$. Relacje między Polakami zamieszkującymi Bejrut i ośrodkami znajdującymi się w górach były bardzo słabe, pomimo istniejących połączeń autobusowych. Członkowie wspólnoty polskiej spotykali się w instytucjach polskich, takich jak Dom Polski, YMCA czy też wspomniany już „Bratniak”.

\section{Ośrodek uchodźczy wyróżniający się pod względem społecznym}

\subsection{Ośrodek o charakterze cywilnym}

Specyfika wspólnoty polskiej w Libanie wynikała również z jej składu społecznego. Niewiele dokumentów opisujących szczegóły akcji przemieszczenia uchodźców do Libanu przetrwało do naszych czasów, jednak zachowane notatki i korespondencja dyplomatyczna pozwalają sądzić, że planom utworzenia nowego ośrodka uchodźczego towarzyszyła refleksja nad jego ukształtowaniem społecznym.

Społeczność polska w Libanie pod wieloma względami podobna była do innych polskich ośrodków uchodźczych zamieszkanych przez rodziny żołnierzy armii Andersa.

Ogłoszenie o repatriacji organizowanej przez UNRRA, „Przelotem” 1946, nr 111, s. 2.

34 Informacje udzielone przez B.K., byłą studentkę Uniwersytetu Amerykańskiego w Bejrucie, $15 \mathrm{~V}$ $2014 \mathrm{r}$.

35 Informacje udzielone przez H.W., byłą studentkę Uniwersytetu Amerykańskiego w Bejrucie, 2 IV $2014 \mathrm{r}$. 
Podobnie jak w Afryce, większość wspólnoty stanowiły kobiety i dzieci. We wrześniu 1946 r., w momencie apogeum polskiej obecności w Libanie, na łączną liczbę 4325 uchodźców składało się 2408 kobiet (55,5\%), 1159 osób poniżej osiemnastego roku życia $(26,8 \%)$ i tylko 758 mężczyzn $(17,5 \%)^{36}$. Dysproporcje te najsłabsze były w Bejrucie (280 mężczyzn, 763 kobiet, 118 dzieci), co tłumaczyć można silną obecnością studentów i głównych instytucji uchodźczych. W miejscowościach poza Bejrutem zdecydowanie przeważały kobiety z dziećmi, szczególnie w ośrodkach w Ghazir i Zouk ${ }^{37}$. Dominacja kobiet i dzieci kontrastowała natomiast z obozami uchodźczymi w Europie, w których większość uchodźców stanowili mężczyźni, co przypisywać można okolicznościom, w jakich polscy DPs znaleźli się na terenie III Rzeszy.

Wśród uchodźców obecnych w Libanie wielu należało do grupy, którą można określić mianem inteligencji. Wola wysłania tam osób wykształconych była obecna już na etapie tworzenia nowego ośrodka, o czym świadczy istnienie „listy syryjskiej” sporządzonej przez polski Konsulat Generalny w Bejrucie, zawierającej nazwiska osób, które miały zostać przewiezione do Libanu ${ }^{38}$. Choć pierwszeństwo mieli studenci, przedstawiciele władz polskich w Teheranie nalegały, aby wpisać na listę również rodziny wojskowe i osoby chore ${ }^{39}$. Do Kraju Cedrów trafili przedwojenni przedstawiciele polskiej kultury i nauki, tacy jak historyk Stanisław Kościałkowski, profesor Uniwersytetu im. Stefana Batorego w Wilnie, lub Maria Anna Tyszkiewiczowa, lepiej znana jako Hanka Ordonówna, zmarła w Bejrucie w 1950 r. O wysokim odsetku osób należących do inteligencji donosił także autor artykułu zatytułowanego Uchodźstwo polskie w Libanie, opublikowanego w styczniu 1946 r. w periodyku wojskowym „Parada”, w którym opisywał on Polaków w ośrodku Ghazir jako rodziny wojskowe, głównie należące do kręgów inteligenckich ${ }^{40}$.

Struktura społeczna odznaczająca się silną obecnością intelektualistów była wskazywana przez urzędników UNRRA i IRO jako główna przeszkoda do likwidacji polskiego ośrodka uchodźczego w Libanie. W wewnętrznej korespondencji organizacji międzynarodowych często podkreślano jego ,inteligencki” charakter, uwidoczniony również w licznych statystykach. Raport opisujący działania IRO na Bliskim Wschodzie w 1948 r. wspominał o problemie około tysiąca uchodźców, którzy jako intelektu-

36 IPMS, A 19 III/11, liczby przedstawione w raporcie Eugeniusza Kocupera, delegata ITC w Bejrucie do dyrektora departamentu spraw socjalnych ITC w Londynie 27 IX $1946 \mathrm{r}$.

37 Ibidem.

38 IPMS, A 11 E 365, list Ministra Stanu w Kairze do Karola Badera, posła RP w Teheranie, z 12 I 1945 r.; ibidem, list Z. Zawadowskiego do Ministerstwa Spraw Zagranicznych Rządu RP na Uchodźstwie z 28 XII 1944 r., s. 1-2.

39 Ibidem, A 18 7, protokół z posiedzenia komisji międzyministerialnej w dniu 2 VI 1944 r. w Teheranie.

40 Ibidem, KOL 380/IVB, Uchodźstwo Polskie w Libanie, „Parada” 1946, nr 4, s. 2. 
aliści pozbawieni byli wyraźnych perspektyw na przyszłość ${ }^{41}$. W aneksie do listu wysłanego do centrali IRO we wrześniu 1948 r. Maurice Lush zamieścił tabelę klasyfikującą uchodźców w Afryce i na Bliskim Wschodzie według profesji. Pokazuje ona wyraźnie, że to właśnie w Libanie odsetek osób należących do inteligencji lub do wyższej klasy średniej był największy.

\begin{tabular}{|l|c|c|}
\hline \multicolumn{1}{|c|}{ Profesja } & Liban & Afryka \\
\hline Rolnicy & $9 \%$ & $21 \%$ \\
\hline Niewykwalifikowani robotnicy & $2 \%$ & $13 \%$ \\
\hline Wykwalifikowani robotnicy & $16 \%$ & $12 \%$ \\
\hline Rzemieślnicy & $22 \%$ & $14 \%$ \\
\hline Profesjonaliści ${ }^{1}$ & $16 \%$ & $7 \%$ \\
\hline Służba & $7 \%$ & $16 \%$ \\
\hline Inne $^{2}$ & $22 \%$ & $9 \%$ \\
\hline
\end{tabular}

Tab. 2. Klasyfikacja zawodowa polskich uchodźców w Libanie i w Afryce Wschodniej ${ }^{42}$

Choć szacunki IRO są ważnym wskaźnikiem pozwalającym poprzeć liczbami dane zawarte w dokumentach polskich, należy do nich podchodzić z dystansem. Statystyki przytoczone przez Lusha powstały pod koniec 1948 r., w momencie gdy większość uchodźców kwalifikująca się do repatriacji lub dalszej emigracji opuściła już Liban. Sporządzone przez IRO dane dotyczyły 1592 uchodźców pozostających w Libanie oraz 4328 osób w Afryce, których wyjazd do Europy został opóźniony z powodów administracyjnych i proceduralnych. W 1948 r. z Libanu wyjechały już rodziny polskich żołnierzy, niewielka grupa repatriantów, a także większość osób mogących liczyć na szybszą relokację do innych krajów.

W terminologii biurokratycznej stosowanej przez IRO przedstawiciele inteligencji tworzyli tzw. grupę hard core ${ }^{43}$, której członkowie najmniej kwalifikowali się do emigracji do krajów takich jak Wielka Brytania, Australia lub Kanada. Istotnie, państwa te najchętniej przyjmowały na swoje terytorium uchodźców zdolnych do prostej pracy fizycznej, szczególnie w kontekście powojennej odbudowy. Osoby należące do inteligencji, z których wiele pochodziło z wyższych sfer społecznych, postrzegane były jako jednostki ekonomicznie niewydajne, przez co ich imigracja nie była priorytetowa. Aby ułatwić ich dalszą emigrację, władze IRO przeprowadzały zakrojone na szeroką skalę akcje promujące zalety tych na pierwszy rzut oka „nieprzydatnych” uchodźców, publi-

\footnotetext{
41 ANF, AJ/43/1056, raport dotyczący działań IRO na Bliskim Wschodzie, s. 3.

42 ANF, AJ/43/1056, list M. Lusha do centrali IRO w Genewie z 11 IX 1948 r.

43 Termin stosowany przez IRO, aby określić uchodźców niespełniających wymogów krajów emigracji.
} 
kując broszury i materiały podkreślające korzyści wynikające z przyjęcia na swoje terytorium intelektualistów ${ }^{44}$.

\subsection{Liban jako centrum kulturalne Polski na uchodźstwie?}

Wyższe uczelnie na ziemi libańskiej przyciagały Polaków przebywających na Bliskim Wschodzie już od 1940 r., gdy na terenie Syrii, a następnie Palestyny formowano pierwsze oddziały Brygady Strzelców Karpackich. Już wtedy pierwsi żołnierze oddelegowywani byli do Bejrutu w celu dokończenia rozpoczętych w Polsce studiów. Liczba ta znacznie wzrosła po przybyciu do Iranu armii Andersa. Staraniem posła Zawadowskiego wizę libańską dostawali w pierwszej kolejności uchodźcy chcący kontynuować kształcenie na uczelniach libańskich, o czym świadczą liczne telegramy wymieniane między konsulatem, później poselstwem polskim w Bejrucie a poselstwem w Teheranie. Wiza przyznawana była w momencie uzyskania przez placówkę w Bejrucie zapewnienia o przyjęciu przez uczelnię studenta polskiego na podstawie polskiego dyplomu maturalnego ${ }^{45}$.

W przeciagu prawie 7 lat około 400 Polaków studiowało na francuskojęzycznym Uniwersytecie św. Józefa (Université Saint-Joseph), anglojęzycznym Uniwersytecie Amerykańskim (American University of Beirut) oraz w Libańskiej Akademii Sztuk Pięknych (Académie libanaise des beaux-arts) $^{46}$. Uchodźcy wybierali najczęściej kierunki ścisłe, takie jak medycyna czy architektura, przeważnie ze względów językowych, choć niewielka grupa studentów decydowała się na studia humanistyczne. Listy autorstwa posła Zawadowskiego pozwalają sądzić, że uczelnie libańskie z pewną rezerwą przyjmowały Polaków, szczególnie kobiety, które naówczas były praktycznie nieobecne na bliskowschodnich uniwersytetach. Świadome przejściowego pobytu polskich studentów w Libanie, władze uczelni niechętnie przyznawały dodatkowe miejsca uchodźcom z uwagi na bardzo duże zainteresowanie lokalne. Problemy językowe, a także rozbieżności programowe stanowiły główne przeszkody dla polskich studentów ${ }^{47}$.

Kwestia kształcenia uchodźców, na poziomie szkolnym i akademickim, stała się ważnym elementem ideologicznym uchodźstwa polskiego po II wojnie światowej. W mniemaniu polskich władz dyplom uniwersytecki miał pozwolić młodemu uchodźcy znaleźć pracę w nowych realiach, a także przygotować go do rychłego powrotu do wolnej Ojczyzny. Z tego powodu urzędnicy poselstwa i delegatury MPiOS w Bejrucie zachęcali

44 Szczególnie interesująca publikacją tego typu jest broszura zatytułowana The Forgotten Elite: The Story of Refugee Specialists (Genewa 1950), w której autorzy przedstawiają sylwetki kilkunastu intelektualistów przebywających w obozach uchodźczych w Europie, ich życiorys, jak i potencjalne specjalizacje.

45 K. Kantak, op. cit., s. 113.

46 Pod cedrami Libanu..., s. 207-215.

47 IPMS, A 11 E 365, list Z. Zawadowskiego do delegata Ministerstwa Wyznań Religijnych i Oświecenia Publicznego Rządu RP na Uchodźstwie w Jerozolimie z 24 III 1945 r. 
studentów do wybierania kierunków ścisłych. Po przybyciu do Libanu wybrana osoba miała obowiązek spotkać się z kierownikiem wydziału oświaty poselstwa, aby ten zaaprobował wybór studiów. Utrzymanie polskich studentów w Libanie, a także opłacenie wysokiego czesnego przypadało władzom polskim, które wypłacały studentom specjalny dodatek miesięczny. Obfita korespondencja Zygmunta Zawadowskiego z Ministerstwem Spraw Zagranicznych rządu na uchodźstwie wskazuje na poważne trudności finansowe, z jakimi borykało się poselstwo i które zmusiły je do sprzedaży ruchomości, aby opłacić koszty związane ze studiami uchodźców ${ }^{48}$.

W notatce wystosowanej przez Ministerstwo Wyznań Religijnych i Oświecenia Publicznego Rządu RP w Londynie stwierdzono, że edukacja na emigracji winna nie tylko wpajać przywiązanie do wartości demokratycznych, a także ideę poświęcenia obywatelskiego w imię dobra publicznego, ale również przygotować do życia za granica poprzez tworzenie poczucia braterstwa i przyjaźni wobec innych nacji, ras i religii ${ }^{49}$. W $1946 \mathrm{r}$. w Libanie znajdowało się osiem polskich szkół podstawowych oraz gimnazja i licea w Ghazir, Zouk i Baabdat, z których niektóre funkcjonowały aż do lata 1950 r. Główną bolączką były duże różnice wiekowe zmuszające władze szkolne do adaptacji programów i łączenia klas. Wraz z wyjazdami kolejnych uchodźców, szczególnie w 1948 r., następowała potrzeba likwidacji niektórych szkół i przenoszenia rodzin z dziećmi do innych ośrodków. Z tego samego powodu władze oświatowe rekrutowały na stanowiska nauczycielskie osoby nieposiadające odpowiedniego przygotowania pedagogicznego, co niekorzystnie wpływało na poziom kształcenia ${ }^{50}$.

Prężność kulturalna polskiego ośrodka w Libanie nie sprowadzała się jedynie do obecności studentów. W 1945 r. powstał w Bejrucie Instytut Polski, z inicjatywy wspomnianego już profesora Stanisława Kościałkowskiego, który przejął schedę po Instytucie Studiów Irańsko-Polskich, założonym w Teheranie tuż po przybyciu do Iranu polskich uchodźców z ZSRR. Na szczególną uwagę zasługuje działające przy Instytucie wydawnictwo Cedr i Orzeł, które publikowało dzieła dotyczące relacji polsko-arabskich. Celem tej instytucji, działającej do 1950 r., było propagowanie kultury polskiej w Libanie, a także jak najlepsze udokumentowanie obecności polskiego uchodźstwa w Kraju Cedrów. Instytut organizował również liczne kursy dokształcające i kółka zainteresowań, jak kurs drukarski lub kurs wykładów prawa polskiego, zainicjowany przez Koło

48 Ibidem, A 11 E 760, list Z. Zawadowskiego do Ministerstwa Spraw Zagranicznych Rządu RP na Uchodźstwie w Londynie z 1 VII 1948 r. na temat polskich absolwentów libańskich uczelni wyższych.

49 Ibidem, A 19 III/11, uwagi dotyczące oświaty polskiej na uchodźstwie.

50 K. Kantak, op. cit., s. 120; Kamil Kantak krytykuje w swojej książce nauczycieli posiadających jedynie wykształcenie podstawowe. 
Prawników Polskich w Libanie ${ }^{51}$. Pomimo trudności natury materialnej i logistycznej Liban był ważnym centrum kulturalnym na mapie uchodźstwa polskiego na świecie.

\section{Polskie uchodźstwo w Libanie w kontekście powojennej sytuacji politycznej}

\subsection{Działanie organizacji rządu warszawskiego wśród uchodźstwa polskie- go w Libanie}

Wycofanie uznania rządowi RP w Londynie w lipcu 1945 r. okazało się kluczowe dla sprawy polskiego uchodźstwa na świecie, gdyż tak rząd emigracyjny, jak i nowy rząd warszawski starały się rozciagać kontrolę nad wychodźcami. Wpływy obu stron były w dużej mierze zależne od obszaru, na którym znajdowało się dane skupisko uchodźców, jego składu społecznego, a także stosunku władz lokalnych do sprawy polskiej. Po uzyskaniu uznania przez większość krajów europejskich władze warszawskie stały się głównym partnerem dla rządów oraz międzynarodowych organizacji do spraw uchodźczych. Choć urzędnicy lojalni wobec Londynu byli marginalizowani, w praktyce rząd na uchodźstwie mógł skutecznie przeciwstawiać się próbom repatriacji, w szczególności w ośrodkach pozaeuropejskich.

Polska społeczność w Libanie nie była podatna na infiltrację komunistyczną z przyczyn zarówno społecznych, jak i politycznych. W przeciwieństwie do innych ośrodków w Europie, ale także Palestynie propaganda na rzecz rządu warszawskiego nie znalazła poparcia uchodźstwa ${ }^{52}$. Nie mogła również liczyć na organizacje o orientacji komunistycznej. Awangardą rządu warszawskiego w Libanie miał być powstały 15 stycznia 1946 r. Polski Komitet Obywatelski Jedności Narodowej (PKOJN), jednak okoliczności utworzenia tej organizacji pozostają niejasne ${ }^{53}$. W zamyśle swoich twórców organizacja ta miała stać się alternatywą dla londyńskich organizacji uchodźczych. W tym celu, poza misją propagandowa, PKOJN miał grać rolę społeczną poprzez takie inicjatywy, jak kółka dyskusyjne, rozpowszechnianie informacji o warunkach życia w Polsce lub publikowanie biuletynu informacyjnego $0^{54}$. Komitet miał także przygotować teren przed przybyciem misji repatriacyjnej poprzez kolportowanie materiałów zachęcających do powrotu do Polski oraz sporządzanie list uchodźców zainteresowanych repatriacją.

51 Pod cedrami Libanu..., s. 14.

52 J. Pietrzak, op. cit., s. 393-395; autor dobrze opisuje wpływy organizacji komunistycznych wśród uchodźstwa polskiego na terenie Palestyny.

53 Archiwum Akt Nowych w Warszawie (dalej cyt.: AAN), 2/197/0, Polski Komitet Obywatelski Jedności Narodowej w Libanie [Bejrut], [inwentarz teczki], s. 2.

54 Ibidem, s. 4. 
PKOJN, który istniał jedynie 10 miesięcy, od momentu swojego powstania napotykał liczne przeszkody. W teorii organizacja była zależna finansowo od delegata rządu warszawskiego w Palestynie i Transjordanii, a następnie od konsulatu generalnego w Tel Awiwie, przejętego przez przedstawicieli nowych władz polskich ${ }^{55}$. Zachowane dokumenty potwierdzaja kontakt PKOJN z warszawskimi placówkami dyplomatycznymi, choć relacje te miały charakter niestały. W praktyce praca komitetu była bardzo ograniczana przez działania poselstwa polskiego w Bejrucie, lokalnych komitetów uchodźczych w poszczególnych ośrodkach i duszpasterstwa, skutecznie udaremniające wszelkie próby dotarcia PKOJN do uchodźców. Organizacja ta cierpiała również na brak osobistości, których autorytet pozwoliłby na przyciagnięcie większej liczby osób. Mając na uwadze ukształtowanie społeczne uchodźstwa w Libanie oraz przeżycia wojenne tej grupy, należy sądzić, że misja propagandowa PKOJN od początku jego istnienia miała nikłe szanse na powodzenie.

Agenci Urzędu do Spraw Repatriacji w Warszawie często nie mieli możliwości efektywnego działania ze względu na silną pozycję, jaką zachowali przedstawiciele emigracji londyńskiej w Libanie. Reprezentanci rządu warszawskiego wielokrotnie krytykowali władze brytyjskie za ułatwianie rozpowszechniania „reakcyjnej propagandy” wśród uchodźstwa polskiego na Bliskim Wschodzie poprzez obsadzanie kluczowych stanowisk w instytucjach takich jak ITC ludźmi lojalnymi wobec rządu na uchodźstwie ${ }^{56}$. Postawa Brytyjczyków rzeczywiście była niejasna i ambiwalentna, w wielu wypadkach zależna od osobistych sympatii i relacji z polskimi przedstawicielami. Pomimo nalegań ze strony PKOJN reprezentanci Rządu Jego Królewskiej Mości nie zdecydowali się na wymuszenie wymiany władz uchodźczych, po części z powodów pragmatycznych. Nie ulegało bowiem wątpliwości, że ustanowienie nowych przedstawicieli o sympatiach prowarszawskich nie spotkałoby się z akceptacją ze strony większości polskiej społeczności w Libanie.

Urzędnicy rządu warszawskiego z pewnym dystansem podchodzili do inicjatywy PKOJN. Być może z tego powodu aktywność komitetu była mocno ograniczona. Jego przewodniczaccy wielokrotnie skarżyli się na brak środków pozwalających rozwinąc przedsięwzięcia o charakterze propagandowym. Szczególnie krytycznie o władzach PKOJN wypowiadali się członkowie misji repatriacyjnej, która przybyła z Warszawy do Bejrutu we wrześniu 1946 r. w celu zorganizowania powrotu uchodźców do Polski. W swoim raporcie opisującym przebieg misji kapitan Tadeusz Kozub wspomina o roz-

55 Ibidem, s. 3.

56 AAN, 2/522/0, Generalny Pełnomocnik Rządu RP do Spraw Repatriacji w Warszawie, Sprawozdanie z konferencji 10 V 1946 r. w lokalu UNRRA w Jerozolimie. Polscy urzędnicy oskarżali w nim władze brytyjskie o świadome utrzymywanie przedstawicieli rządu na uchodźstwie na kluczowych stanowiskach w ITC. 
dźwięku pomiędzy rzeczywistością w terenie a relacjami PKOJN, które Urząd do Spraw Repatriacji uzyskał przed przyjazdem do Libanu. Kozub stwierdza, że „oficjalnie podana cyfra 1500 osób przygotowanych już do repatriacji przez zarząd PKOJN, nie licząc wiele innych [...], jest mocno przesadzona”, zaś „,wiele do życzenia pozostaje zarządowi PKOJN, który jest bez wytycznych i bez wyrobienia politycznego”, przez co ,zamiast jedności wysuwają się osobiste ambicje, które są powodem wielu intryg, wystąpień osobistych i niepowodzeń”. Kozub podsumowuje, że „wszystko to szkodliwie wpływa na wyniki pracy społecznej, zamiast utrwalać osłabia się własne pozycje" ${ }^{27}$. Raport jednoznacznie potwierdza, że „teren miejscowy nie został przygotowany do repatriacji” ${ }^{58}$.

Władze warszawskie zdawały sobie sprawę z nikłych szans na powodzenie misji repatriacyjnej wśród żołnierzy armii Andersa i ich rodzin. Wielokrotnie podkreślano niska „,wartość społeczną" uchodźców znajdujących się stale pod wpływem Londynu. We wspomnianym już raporcie Kozub stwierdza, że „element tutejszy [w Libanie] jest przeciętny [...] na wskroś zgangrenowany jadem propagandy, a społecznie całkiem bezwartościowy”. Problem ten dotyczy także „członków org. PKOJN, którzy w wielu przypadkach jeśli jeszcze nie byli w lokalu, to omijaja go, nie mając odwagi cywilnej na przekroczenie progu, nie mówiąc już o ich aktywności społecznej na zewnątrz" 59 . Słabe perspektywy powrotu uchodźców do Polski doprowadziły do zakończenia misji repatriacyjnej na Bliskim Wschodzie już w listopadzie 1946 roku, miesiąc po likwidacji PKOJN w Libanie.

\subsection{Uchodźcy polscy w Libanie a międzynarodowe organizacje do spraw uchodźczych}

Autonomia, jaką dysponowała społeczność polska w Libanie, a także wrogość jej przewodniczących wobec nowych władz polskich postrzegane były przez międzynarodowe agendy do spraw uchodźczych jako jedna z przeszkód uniemożliwiających rozwiązanie ,problemu” uchodźstwa na Bliskim Wschodzie. Choć cele UNRRA i IRO różniły się, procedury mające ułatwić repatriację lub relokację uchodźców na skalę masową nie sprawdzały się w specyficznym kontekście Libanu. Z tego właśnie powodu stosunki między polskimi władzami uchodźczymi a przedstawicielami wyżej wspomnianych instytucji z reguły były napięte, szczególnie w pierwszych miesiącach okresu powojennego, gdy repatriacja jawiła się jako jedyne logiczne i pożądane rozwiązanie problemu uchodźstwa. Szczególną niechęcią darzyli Polacy UNRRA, której urzędnicy w Libanie byli otwarcie oskarżani o sprzyjanie nowym władzom warszawskim.

\footnotetext{
57 AAN, 197/3, Tadeusz Kozub, Sprawozdanie repatriacyjne z terenu libańskiego, Bejrut, 8 X 1946 r., s. 2.

58 Ibidem.

59 Ibidem.
} 
Należy tutaj przypomnieć kontekst, w jakim powstała UNRRA oraz zastępująca ja później IRO. W momencie swojego utworzenia, za zgodą przedstawicieli wielkich mocarstw w 1943 r., UNRRA miała stać się kołem zamachowym dla procesu odbudowy terytoriów dotkniętych działaniami wojennymi, nieść pomoc poszkodowanej w ich wyniku ludności, a także ułatwiać powrót uchodźców. W okresie powojennym ta ostatnia misja stała się główną racją bytu UNRRA, w której gestii znalazły się obozy uchodźcze na terenie Europy. Organizacja ta jednak nie mogła sprostać problemowi uchodźców odmawiających powrotu do państw znajdujących się pod dominacją radziecką, zaś próby rozszerzenia jej mandatu nie powiodły się z przyczyn politycznych. Powstała w $1946 \mathrm{r}$. IRO, bez uczestnictwa ZSRR i krajów satelickich, rozwiązać miała problem uchodźców nie tylko poprzez repatriację (która jednak nadal była uprzywilejowana), ale również poprzez zorganizowaną emigrację, za zgodą państw przyjmujących. Wprowadzenie możliwości relokacji było wymuszone przez dużą liczbę uchodźców niechcących wracać do ojczyzny w kontekście narastających napięć między Wschodem a Zachodem.

W Libanie, gdzie polska społeczność reprezentowana była przez władze prolondyńskie uznawane przez rząd libański, zarówno UNRRA, jak i IRO nie mogły w sposób całkowity przejąc kontroli nad sprawami uchodźczymi. Urzędnikom tych organizacji nie odpowiadała także postawa przedstawicieli brytyjskich pragnących zachować kontrolę nad polskim uchodźstwem w Kraju Cedrów. Szczególnie krytykowane przez przedstawicieli IRO było PRO działające przy ambasadzie brytyjskiej, którego pracownicy polscy mieli utrudniać wszelkie poczynania zmierzające do repatriacji bądź relokacji uchodźców ${ }^{60}$. Brak bezpośredniej kontroli, a także zobowiązanie władz brytyjskich do utrzymania polskiego uchodźstwa sprawiały, że sposoby wywierania presji na Polakach, takie jak redukcja miesięcznych dodatków lub pomocy materialnej, nie sprawdzały się w Libanie.

Należy zaznaczyć, że o ile władze polskie w Libanie skutecznie sabotowały zabiegi UNRRA zmierzające do forsowania repatriacji, o tyle były świadome konieczności osiedlenia uchodźców w jak najszybszym czasie. Odrzucały one jednak rozwiązania IRO, które również było zainteresowane jak najszybszą likwidacją ośrodka w Libanie z powodów finansowych (koszt miesięcznego utrzymania jednego uchodźcy był jednym z najwyższych w skali ogółu uchodźstwa). Zaproponowany w 1948 r. przez IRO plan przesiedlenia pozostających w Libanie Polaków do obozów w Europie, w oczekiwaniu na ich przyjęcie przez zainteresowane kraje, spotkał się z gwałtowna reakcją ze strony polskich władz i polskich organizacji uchodźczych. Wskazywały one na fatalne warunki panujące w ośrodkach na kontynencie europejskim, niepozwalające na przyjęcie pozostałych w Libanie uchodźców, głównie osób starszych i rodzin z dziećmi ${ }^{61}$. Władze IRO

\footnotetext{
${ }_{60}$ ANF, AJ/43/1059, IRO problem in Lebanon, 28 VIII 1948 r., s. 1.

61 Ibidem, AJ/43/1056, list władz PRO do przedstawicieli IRO w Libanie z 31 I 1948 r.
} 
ripostowały, zarzucając Polakom sabotaż, który tylko pogarszał ich sytuację, obniżając szanse na przyjęcie przez jakikolwiek kraj ${ }^{62}$. W ostateczności plan IRO został skutecznie zablokowany dzięki osobistej interwencji posła Zawadowskiego u przedstawicieli rządu włoskiego, który uprzednio wydał pozwolenie na przyjęcie w obozach zlokalizowanych na swoim terytorium uchodźców z Libanu.

Władze polskie również uczestniczyły w wysiłkach związanych z poszukiwaniem potencjalnych krajów, które zechciałyby przyjąć około 1800 uchodźców pozostających w Libanie po 1948 r. Jednak wszelkie próby podejmowane przez polskie instytucje uchodźcze bądź IRO nie przyniosły spodziewanych efektów, głównie z powodu niewielkiego zainteresowania, jakim darzyły uchodźców niezdatnych do pracy fizycznej Argentyna, Australia lub Kanada. Zdecydowana większość Polaków z Libanu trafiła do Wielkiej Brytanii w ramach operacji „Pole jump” w 1948 r. Objęła ona około 1600 członków rodzin polskich żołnierzy. Pozostały w Libanie kontyngent 1300 uchodźców wyjechał do Wielkiej Brytanii w 1950 r.

\section{Wnioski}

W obliczu wyjątkowości polskiego uchodźstwa w Libanie należy zastanowić się, w jakim stopniu można badać tę grupę w perspektywie ogólnej problemu DPs po II wojnie światowej. Starania polskich władz, a także pomyślny z punktu widzenia emigracyjnego rządu polskiego rozwój sytuacji politycznej w Libanie pozwoliły na powstanie ośrodka o charakterze cywilnym. Istotnie, choć w pojęciu organizacji międzynarodowych Polacy obecni w Kraju Cedrów również zaliczali się do kategorii „Displaced Persons”, w korespondencji częściej używano terminu „uchodźcy”, biorąc pod uwagę, że społeczność ta powstała tylko pośrednio z powodu działań wojennych. Sami Polacy w Libanie często woleli uważać się za członków nowej emigracji politycznejej.

Silna pozycja przedstawicieli rządu polskiego na uchodźstwie miała zdecydowany wpływ na proces kształtowania się ośrodka w Libanie oraz na okoliczności jego likwidacji. Przy stale pogarszającej się dla władz polskich w Londynie koniunkturze politycznej działania poselstwa w Bejrucie pozwoliły na zachowanie uznania politycznego ze strony rządu libańskiego, który tym samym, w osobie prezydenta Republiki Libańskiej Bechary al-Khoury’ego, stawał się protektorem wspólnoty polskiej. Uniemożliwiało to w dużej mierze prowadzenie skutecznej akcji propagandowej przez przedstawicieli rządu warszawskiego, co przekładało się na bardzo niski odsetek repatriacji wśród uchodźców

${ }_{62}$ Ibidem, komentarz listu otrzymanego od władz PRO z 4 II 1948 r.
${ }_{63}$ Zastanówmy sie, „Przelotem” 1947, nr 32/222, s. 1. 
w Libanie. Polityczne uznanie przez władze lokalne, jakim cieszyło się przedstawicielstwo polskie w Bejrucie, wzmacniało również pozycję negocjacyjną uchodźców pod koniec lat 40., gdy ważyły się kwestie związane z repatriacją lub relokacja.

Choć przesadą byłoby mówienie o „polskim centrum kulturalnym” w Libanie, istniejące na jego terenie uczelnie wyższe oraz kultura lewantyńska dawały szanse na stworzenie szeregu instytucji kulturalnych mających na celu informowanie o sprawie polskiej. Świadomi specyfiki swojej społeczności, uchodźcy skrupulatnie udokumentowali swój pobyt w Kraju Cedrów, który opisany został w szczególności przez Stanisława Kościałkowskiego i Kamila Kantaka. Po emigracji do Wielkiej Brytanii byli członkowie „Bratniaka” założyli „Koło Bejrutczyków”, zrzeszające byłych studentów uczelni bejruckich. Dzięki wysiłkowi włożonemu w opisanie życia Polaków w Libanie możliwe jest dzisiaj skonfrontowanie źródeł administracyjnych z głosem samych uchodźców, który zbyt często nie był brany pod uwagę.

Specyfika ośrodka polskiego w Libanie na tle ogółu uchodźstwa była najbardziej widoczna w życiu codziennym, które większość świadków opisywała w swoich wspomnieniach jako wspaniałe. W przeciwieństwie do cieszących się złą sławą obozów dipisów w Niemczech, Austrii i Włoszech, skupiających dziesiątki tysięcy uchodźców, Polacy w Libanie dysponowali dużą swobodą. Relatywna anonimowość, a także potrzeba radzenia sobie z trudnościami życia w odmiennych realiach kulturowych dawały namiastkę normalności, której brakowało w przeludnionych ośrodkach w Europie. Uchodźcy z chęcią nawiązywali relacje z Libańczykami, choć często były one ograniczone przez bariery językowe. Kontakty te, na mniejszą skalę, miały miejsce codziennie, na uczelniach, w sklepach, w transporcie miejskim lub w mieszkaniach wynajmowanych od tubylców, przygotowując niejako uchodźców do późniejszego życia na emigracji.

Choć istnieje pokusa oderwania historii Polaków w Libanie od ogółu problemu uchodźstwa po II wojnie światowej i skoncentrowania się wyłącznie na jego specyfice, przypadek ten pozwala także zwrócić uwagę na wciąż niedostatecznie opisaną kwestię relacji między uchodźcami a agendami międzynarodowymi odpowiedzialnymi za rozwiązanie problemu DP. To właśnie w Libanie urzędnicy UNRRA i IRO zmuszeni byli do negocjowania z władzami uchodźczymi oraz do dostosowywania istniejaccych procedur sprawdzających się w obozach dipisów w Europie. Historia polskiego uchodźstwa w Libanie może więc z powodzeniem być analizowana na wielu płaszczyznach, zarówno w wymiarze polskim, jak i międzynarodowym. 


\section{Bibliografia}

Źródła archiwalne:

Archiwum Akt Nowych w Warszawie

2/197/0, Polski Komitet Jedności Narodowej w Libanie [Bejrut].

2/522/0, Generalny Pełnomocnik Rządu RP do Spraw Repatriacji w Warszawie.

\section{Archives nationales de France w Paryżu}

AJ/43/1056, Organisation internationale pour les réfugiés, „Moyen Orient”.

AJ/43/1059, Organisation internationale pour les réfugies, „Moyen Orient”.

\section{Instytut Polski i Muzeum im. gen. Sikorskiego w Londynie}

A 11 E 365, Ministerstwo Spraw Zagranicznych, Wewnętrzne sprawy placówki - Bejrut.

A 11 E 760-762, Ministerstwo Spraw Zagranicznych, Korespondencja z placówkami: Liban.

A 18 7, Ministerstwo Pracy i Opieki Społecznej (Referat Wschodni), Protokoły z konferencji Komisji Międzyministerialnej do spraw uchodźczych.

A 19 III/11, Ministerstwo Wyznań i Oświecenia Publicznego - Akta, 1940-1991, Szkolnictwo poza W. Brytania - Egipt, Liban, Afryka, Palestyna. Sprawy ogólne.

KOL 380 IV/B, X/B, Koło Wychowanków Szkół Polskich Isfahan i Liban.

\section{Prasa uchodźcza}

„Parada”, Kair, styczeń 1946, R. IV, nr 2.

„Polak w Libanie”, Bejrut, maj 1949, R. III, nr 4/40.

„Przelotem”, Bejrut, 26 września 1946, nr 111.

„Przelotem”, 8 lutego 1947, nr 32/222.

„Przelotem”, 18 lutego 1947, nr 40/230.

„Przelotem”, 15 marca 1947, nr 62/252.

\section{Opracowania:}

Ciechanowski J., Konferencja Generata Sikorskiego w Bejrucie 23 kwietnia 1943, „Zeszyty Historyczne” 1985, nr 74, s. 139-148.

Isfahan, the City of Polish Children, eds. I. Beaupre-Stankiewicz, D. Waszczuk-Kamieniecka, J. Lewicka-Howells, London 1989.

Jasionowicz S., Pamiętam... i nie pamiętam... Wybór wspomnień (1940-1950), Warszawa 2016.

Kantak K., Diieje uchod乏́stwa polskiego w Libanie 1943-1950, Bejrut 1955.

Kersten K., Repatriacja ludności polskiej po II wojnie śniatowej, Warszawa 1974.

Pietrzak J., Polscy uchodźcy na Bliskim Wschodzie w latach II wojny swiatowej. Ośrodki, instytucje, organizacje, Łódź 2012.

Pod cedrami Libanu, red. B. Redzisz, H. Adamiak-Wagner, H. Chojecka-Szeremeta, Londyn 1994. 